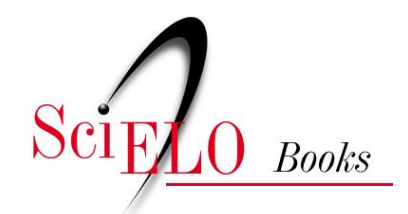

\author{
Capítulo 3 \\ Acordes e textos armoriais \\ Luís Adriano Mendes Costa
}

COSTA, LAM. Antonio Carlos Nóbrega em acordes e textos armoriais [online]. Campina Grande: EDUEPB, 2011. Acordes e textos armoriais. pp. 105-168. ISBN 978-85-7879-186-5. Available from SciELO Books <http://books.scielo.org>.

\title{
(c) $(1)(2)(2)$
}

All the contents of this work, except where otherwise noted, is licensed under a Creative Commons Attribution-Non Commercial-ShareAlike 3.0 Unported.

Todo o conteúdo deste trabalho, exceto quando houver ressalva, é publicado sob a licença Creative Commons Atribuição Uso Não Comercial - Partilha nos Mesmos Termos 3.0 Não adaptada.

Todo el contenido de esta obra, excepto donde se indique lo contrario, está bajo licencia de la licencia Creative Commons Reconocimento-NoComercial-CompartirIgual 3.0 Unported. 
Capítulo 3

Acordes e textos armoriais 



\section{Acordes Armoriais: uma análise instrumental}

A entrada de Antonio Carlos Nóbrega no Movimento Armorial deu-se, como foi visto anteriormente, a partir do Quinteto Armorial. Foi a partir daí que sua vida artística tomou um outro rumo, passando a conhecer mais de perto um outro mundo, até então não apresentado de forma plena. Com o passar dos anos, o artista foi incorporando e conhecendo a música dos violeiros e dos tocadores de pífanos, a poesia e o canto dos cantadores, emboladores e romanceiros, a dança e a representação dos diversos brincantes, artistas ocultos do cavalo-marinho, passistas de frevo, puxantes da conhecida dança guerreira nordestina, os chamados caboclinhos, o sagrado e o profano dos pastoris, entre outros diversos elementos que permeiam a cultura popular brasileira.

É nessa direção que seu trabalho foi pautado, incorporando esses diversos elementos que passam a ser latentes dentro do seu trabalho. A partir desses aspectos, fizemos um levantamento de um dos elementos identificadores dos estilos, nesse caso específico, a análise instrumental dos discos Na Pancada do Ganzá, Madeira que cupim não rói (Na Pancada do Ganzá II), Pernambuco Falando Para o Mundo, O Marco do Meio-Dia e o Lunário Perpétuo. Ao todo, um total de 78 músicas, entre frevos, marchas, maracatus, cocos, xotes, choros, caboclinhos, cirandas, polcas, maxixes, entre outros ritmos. 
Esses discos refletem a influência do Armorial na proposta musical do artista, visto que, foi a partir daí, que se desenhou um trabalho solidificado inteiramente $\operatorname{seu}^{1}$, no que se refere à música, apreendido ao longo dos anos de convívio direto com outros artistas que procuravam, cada um na sua área de atuação artística, consolidar a estética preconizada por Ariano Suassuna.

$\mathrm{Na}$ análise instrumental, foi observada a configuração instrumental presente nos trabalhos recitais do artista a partir da organologia, como foi dito anteriormente. Utilizamos as seguintes categorias: metais (aerofones), cordas (cordofones), percussão (idiofones de altura indefinida); e madeiras (aerofones). Lembramos que os aerofones dizem respeito àqueles instrumentos que têm seus sons extraídos através do ar; cordofones, sons retirados através de cordas; e idiofones de altura indefinida, que são os instrumentos percussivos. Estabelecemos quatro categorias a partir de três formas de classificação dos tipos de sons, tendo em vista que os metais e as madeiras fazem parte do grupo dos aerofones. A partir daí, foi verificada a utilização desses instrumentos dentro da execução de cada uma das músicas.

Ao lançarmos um olhar mais específico sobre esses elementos, observamos uma relativa mistura na utilização de instrumentos que fazem parte do contexto mais erudito, assim como instrumentos vinculados ao popular. Dentro da categoria dos aerofones, por exemplo, foi verificada uma participação efetiva das madeiras, com destaque para a presença da flauta e flautim, com um percentual de $62,8 \%$ de participação na

1 Anteriormente, Antonio Carlos Nóbrega teve, no Quinteto Armorial ,sua experiência maior na música. Com o grupo, o artista participou da produção dos discos Do romance ao galope nordestino, de 1974; Aralume, no ano de 1976; Quinteto Armorial, no ano de 1976; e Sete Flechas, em 1980. 
harmonia das músicas, além do acordeom, utilizado em 61,5\% das músicas, seguido pelo saxofone, com 43,6\%; e pela clarineta, com $28,2 \%$. Já entre os metais, foi verificada a presença do trombone em 26 músicas, um percentual de 33,3\%. O trompete está presente em 23 músicas, formando um percentual de 29,5\%; e, em seguida, vem o bombardino com uma participação de 23,1\% no conjunto das músicas.

Já na categoria dos cordofones, verificou-se a presença marcante do cavaquinho, presente em 40 músicas, o que representa $51,3 \%$ de participação nas músicas dos cinco discos do artista. A rabeca vem logo em seguida com um percentual de 48,7\% das músicas. A partir daí, segue o bandolim com $25,6 \%$; a viola com $24,3 \%$ e o violão de sete cordas com $23,1 \%$. Já o violão está presente em 17 músicas, um percentual de $21,8 \%$; enquanto o violoncelo em $14,1 \%$ das músicas.

No que se refere à categoria dos idiofones de altura indefinida, foi verificada a presença marcante do pandeiro e da caixa em $57,7 \%$ das músicas, ou seja, presente em 45 músicas da discografia do artista cada um dos instrumentos. Em seguida, vem a zabumba, com um percentual de 53,8\%. Já o ganzá está presente em $28,2 \%$ das músicas, seguido pelo tambor de maracatu, com $20,5 \%$; o agogô e os pratos, com $16,6 \%$ cada; e o triângulo, com uma participação em 14,1\% nas músicas do artista.

Verificamos, nessa rápida distribuição dos números obtidos na análise, a forte presença de instrumentos de origem popular, como a rabeca, o cavaquinho, a zabumba, o pandeiro e a viola. Instrumentos que se enquadram naquilo que Ariano Suassuna vislumbrava em sua proposta para a música armorial. Ao lado desses instrumentos, verificamos, também, a presença do acordeom, que junto aos romances, excelências e loas, representa a influência ibérica do passado a que o criador do Movimento Armorial tanto se reportava. Assim como outras experiências 
armoriais em torno da música, como foi o caso do Quinteto Armorial, da Orquestra Armorial de Câmara e da Orquestra Romançal Brasileira, Nóbrega faz uso de instrumentos mais característicos da cultura popular, não deixando de fazer uso dos eruditos.

Ao adotar essa postura, Nóbrega vai muito além do uso de instrumentos. Sua performance, reunindo poesia, dramatização, dança, cenografia, música e, sobretudo, sua caracterização em palco, possibilita uma maior identificação por parte do público, que se reconhece nas diversas possibilidades apresentadas pela versatilidade do artista, que trabalha com elementos diversos da cultura popular, todos reunidos dentro de um único ambiente. Um trabalho repleto, presente na memória coletiva dos diversos públicos, que só pode existir enquanto uma prática vivenciada no cotidiano das pessoas, que celebram "sua revificação, e o mecanismo de conservação do grupo está associado à preservação da memória" (ORTIZ, 1994, p. 133).

Assim como faz referência o Movimento Armorial, Nóbrega mantém uma base com a origem ibérica e a arte popular nordestina, ressaltados como suportes para a "cultura nacional", que busca refletir a cultura autêntica formada na base popular da cultura nordestina, sem nenhuma influência estranha a nossa cultura. Em relação a isso, Suassuna se colocava considerando que essa questão da influência estranha à nossa cultura referese àquela que não faz parte da formação do povo brasileiro, não se estendendo, portanto, à influência ibérica.

Para melhor compreender a realização da análise instrumental adotada no presente estudo, vejamos a seguir um exemplo que ilustra os procedimentos utilizados de forma mais específica na análise instrumental da discografia de Antonio Carlos Nóbrega. 


\section{0 erudito e o popular no $1^{0}$ Movimento do Concerto para Dois Violinos em Ré menor}

Para efeito de apresentação dos procedimentos utilizados na análise instrumental, tomamos o $1^{\circ}$ Movimento do Concerto para Dois Violinos em Ré menor, de Johann Sebastian Bach, a partir de duas versões da peça, sendo a primeira executada por uma orquestra sinfônica estrangeira que caracteriza os elementos eruditos; e a segunda caracterizando o popular, executada pelo músico Antonio Carlos Nóbrega, adaptada para flauta e rabeca, também em ré menor, presente em um dos trabalhos recitais do artista, o disco Na Pancada do Ganzá.

Para essa parte específica da análise, foi levado em consideração, também, um procedimento de análise através de um metrônomo, com o objetivo de verificar a diferença de elaboração no conjunto das obras, quando foi observada uma total diferença na estrutura e na velocidade das duas versões, já que na primeira se mantém uma estrutura rígida e a segunda é executada em três momentos distintos, como será verificado mais à frente.

$\mathrm{Na}$ análise para identificação do erudito, feita a partir da versão orquestrada, levaram-se em conta as características do período Barroco na música, que vai de 1600 a 1750, quando Bach produziu a peça. É nesse período que a música instrumental passa a ter, pela primeira vez, a mesma importância da música vocal.

Nessa versão, foi identificada a ausência de aerofones e idiofones, sendo utilizados apenas os instrumentos que têm seus sons extraídos através de cordas, classificados como cordofones. São eles: Violino, viola, violoncelo, contra-baixo e cravo. Isso deixa clara a questão relativa à presença marcante da família do violino que caracteriza um ponto de destaque dentro do Barroco. Essa família veio substituir a família das violas, tida 
como centro das orquestras até então. Nesse sentido, o violino passou a desempenhar um peso importante na composição da orquestra. A seção de cordas transformou-se no núcleo da orquestra barroca, mas conservando um teclado contínuo (cravo ou órgão), de modo a preencher a harmonia.

Um outro aspecto que predominou, nesse período, foi a presença do baixo contínuo ou baixo cifrado durante toda execução da música, ou seja, tudo que o compositor escrevia sob a melodia resumia-se a uma linha do baixo que deveria ser tocada por algum instrumento grave de corda, como o cello, por exemplo. Essa linha continuava durante toda a execução da peça. Tal característica permaneceu por todo o período Barroco, construindo a base da harmonia e da tessitura de praticamente todo o tipo de música desse período. o baixo contínuo ou baixo cifrado torna-se a base de quase toda a música barroca, fornecendo uma decidida linha de baixo que impulsiona a música para frente, do começo ao fim. Outro traço de destaque nas orquestras barrocas era a presença do órgão ou cravo contínuo, preenchendo a harmonia, enriquecendo a tessitura e, de fato, mantendo a unidade da orquestra. Uma outra forte característica da música orquestral barroca era o contraste:

O compositor barroco está freqüentemente contrastando brilhantes filetes de sons, como dois oboés ou dois trompetes, com um fundo de cordas. Ou pode contrastar 'blocos' sonoros de diferentes timbres - por exemplo, uma passagem para cordas, depois para sopros, e depois a combinação das duas seções. (BENNETT, 1986, p. 43).

Ou seja, como sair do nível forte para o nível piano, e depois fazer um retorno repentino ao forte. Nesse sentido, às vezes uma frase suave pode ser a repetição da precedente, forte, criando um efeito de eco. Principalmente nos concertos, esses efeitos 
de ecos podem ser mais bem verificados, quando se contrastam timbres instrumentais de poucos instrumentos contra muitos, e de sonoridades fortes e suaves.

Já na versão produzida pelo artista Antonio Carlos Nóbrega, verificou-se uma diversidade bem maior na instrumentação utilizada. Nela, estão presentes a flauta, o acordeom e o sax alto, na categoria aerofone; a rabeca, o bandolim, o cavaquinho e o violão de sete cordas, na categoria cordofone; e a caixa, o pandeiro e a zabumba, na classe dos idiofones de altura indefinida.

Existe aí a predominância de instrumentos de cunho popular na execução da peça, como é o caso da rabeca, pandeiro, zabumba, cavaquinho, violão e acordeom. Instrumentos que, independente da sua origem, estão ligados ao aspecto popular da nossa cultura e se tornam elementos próximos, servindo de referência.

Uma característica que merece destaque dentro da versão popular é quanto à alteração da estrutura básica da música, criando três ambientes diferentes. Inicialmente, uma marcharancho, para num segundo momento executar um chorinho e, por fim, um terceiro ambiente executado através de um frevo. Todos, ritmos que surgem no Brasil, num processo de criação em contextos populares da nossa sociedade:

Surgidos no fim do século XIX entre os núcleos de moradores nordestinos da zona portuária do Rio de Janeiro, ligados todos a uma origem rural (foram os baianos migrados para o Rio que tiveram a idéia de desfilar com ranchos no carnaval), os primeiros ranchos cariocas saíam cantando pelas ruas as marchas e loas do repertório tradicional do ciclo de festas folclóricas de dezembro. (TINHORÃO, 1986, p. 132). 
O segundo ritmo executado pelo artista é o chorinho, música de câmara que também tem suas origens no contexto popular da nossa cultura:

O aparecimento do choro, ainda não como gênero musical, mas como forma de tocar, pode ser situado por volta de 1870, e tem sua origem no estilo de interpretação que os músicos populares do Rio de Janeiro imprimiam à execução das polcas, que desde 1844 figuravam como o tipo de música de dança mais apaixonante introduzido no Brasil. [...] Os componentes dos conjuntos de chorões cariocas do fim do século XIX e do início do presente século eram, na sua quase totalidade, representantes da baixa classe média do Segundo Império e da República. (TINHORÃO, 1986, p. 103-105).

O terceiro e último momento da versão do artista Antonio Carlos Nógrega dá lugar a um outro ritmo que surge num processo de transformação, a partir de outros ritmos presentes, também, num contexto popular. Trata-se do frevo:

o frevo pernambucano figura, ao lado do maxixe carioca, entre as mais originais criações dos mestiços da baixa classe média urbana brasileira, no campo da música e da dança. [...] Criação de músicos brancos e mulatos, na sua maioria instrumentistas de bandas militares tocadores de marchas e dobrados, ou componentes de grupos especialistas em música de dança do fim do século XIX (polcas, tangos, quadrilhas e maxixes), o frevo fixou sua estrutura numa vertiginosa evolução 
da música das bandas de rua, de inícios da década de 1880 até os primeiros anos do século XX. Os estudiosos do frevo pernambucano, embora discordando em vários pontos quanto a pormenores de sua história, são unânimes em concordar que as origens do passo (nome atribuído às figurações improvisadas pelos dançarinos ao som da música) se prendem à presença de capoeiras nos desfiles das ruas mais famosas bandas de músicas militares do Recife da segunda metade do século XIX: a banda do $4^{\circ}$ Batalhão de Artilharia, chamado o Quarto, e a da Guarda Nacional, conhecida por Espanha. (TINHORÃO, 1986, p. 138).

Verificamos aí a utilização de três ritmos populares. Uma marcha-rancho, um chorinho e, por fim, um frevo. Ritmos que surgem em ambientes próprios das camadas mais populares da nossa sociedade.

Enquanto na versão erudita mantém-se a mesma estrutura da música do início ao fim, com uma velocidade de 96 batidas por minuto (BPM), a versão popular apresenta-se dividida em três momentos distintos, com variação entre eles, apresentando, respectivamente, 118 durante a marcha-rancho; 94 no chorinho; e 138 batidas por minuto, com o frevo. Verifica-se aí a versatilidade da obra popular, com uma variação de elementos que enriquecem ainda mais a obra original, já que a primeira versão mantém uma única estrutura na execução da música.

Além dos três momentos, a versão de Nóbrega apresenta, ainda, um outro elemento que merece atenção especial, que diz respeito à menção feita pelo artista ao choro Escadaria, utilizado como cadência na execução da música, o que se caracterizaria como mais um elemento que ressalta a versatilidade e a 
possibilidade de recriação do popular. Enquanto Bach, imerso no estilo barroco, em que todos os instrumentos dialogam cada qual com uma linha melódica diferente, Nóbrega se apropria dessa estrutura composicional contrapontística e insere um contexto mais popular à obra.

Encontramos aí um exemplo claro da proposta armorial de criação, a partir de obras anteriores, ou melhor dizendo, de recriação das artes. Ao trabalhar com a peça $1^{\circ}$ Movimento do Concerto para Dois Violinos em Ré menor, Nóbrega amplia as possibilidades da música, incorporando a ela outros elementos que tornam possíveis observações diferentes acerca da mesma. É o que acontece quando ele se utiliza de instrumentos ligados ao popular da nossa cultura, como a rabeca, pandeiro, zabumba, cavaquinho, violão e acordeom, possibilitando uma interpretação diferente, ou melhor dizendo, uma identificação maior. 0 mesmo acontece, também, quando ele modifica a estrutura da música, incorporando ritmos que surgem no contexto popular da nossa cultura, além do choro Escadaria, utilizado como cadência na execução da música, algo que seria impossível de se verificar na estrutura rígida da versão erudita.

Uma obra que passou por um processo de reescrição, reelaboração, possibilitando, junto a essas modificações, outras possíveis análises, mais próximas e mais representativas da cultura popular e, por extensão, da região Nordeste. Ao incorporar elementos mais próximos da nossa cultura, como os ritmos e instrumentos, nesse caso específico, no $1^{\circ}$ Movimento do Concerto para Dois Violinos em Ré menor, Nóbrega faz uma interconexão entre elementos e facilita a assimilação e identificação por parte do público, uma reelaboração de uma obra Barroca, a partir da concepção de recriação das artes. 


\title{
Textos Armoriais: as letras falam por si
}

Como podemos ver, toda a obra de Antonio Carlos Nóbrega reflete não apenas a sobrevivência, mas, também, a permanência do Armorial no fazer artístico contemporâneo, embora saibamos que não exista o espaço devido para divulgação de trabalhos artísticos dessa natureza. Essa forma de trabalho vai refletir diretamente no maior reconhecimento por parte do público, quanto à representatividade da arte Armorial.

Nas letras das suas músicas, vamos encontrar um forte apego a algumas das propostas centrais da estética do Movimento, como acontece com os aspectos temáticos, com núcleos narrativos extraídos diretamente do romanceiro, como é o caso da música Vinde, vinde, moços e velhos (presente em duas versões nos discos Na Pancada do Ganzá e Pernambuco Falando para o Mundo), chamamento que já existe há mais de um século, despertando paixões dos partidários dos cordões azul e encarnado do Pastoril, na eterna disputa entre os dois lados:

\author{
Vinde, vinde, \\ moços e velhos, \\ vinde todos apreciar. \\ Como isso é bom, \\ Como isso é belo. \\ Como isso é bom, \\ É bom demais. \\ Olhai, olhai, \\ Admirai. \\ Como isso é bom, \\ É bom demais.
}


Se no disco Pernambuco Falando para o Mundo, existe a saudação de boas vindas para a participação dos "moços" e "velhos" no Pastoril, nesse mesmo disco, encerrando o trabalho, existe também o momento do adeus com a canção Despedida, também extraída do domínio público, com a participação de Wilson Freire.

\author{
Às cinco horas da manhã, \\ quando vem rompendo a aurora, \\ os anjos cantam no céu, \\ e as pastorinhas vão embora. \\ Com saudades eu me retiro, \\ que eu não vim para ficar. \\ As moças são deliciosas, \\ belas e formosas, \\ lindas como as rosas. \\ Já falta pouco para o sol \\ vir nos braços da aurora, \\ vem pra ficar com vocês \\ para levar-nos embora. \\ Vivendo de palco em palco \\ entre chegadas e partidas \\ estamos nós outra vez, \\ na hora da despedida. \\ Nós, brincantes, nos retiramos \\ não viemos pra ficar. \\ A vida de um menestrel \\ é sem porto e ao léo, \\ sempre a caminhar.
}


O uso das formas poéticas do romanceiro popular nordestino, com a utilização de algumas de suas formas, seja do martelo agalopado, do galope à beira mar, do martelo gabinete, ou do simples repente, reflete, também, diretamente num outro princípio Armorial. São vários os exemplos nos trabalhos recitais de Nóbrega, a exemplo das músicas Meu Foguete Brasileiro, escrita na forma de Galope à Beira-mar (estrofes de onze sílabas, em dez versos, com rimas ABBAACCDDC), uma das formas mais trabalhadas pelos cantadores; e a música Carrossel do Destino, exemplo apresentado a seguir:

\author{
Deixo os versos que escrevi, \\ as cantigas que cantei, \\ cinco ou seis coisas que eu sei \\ e um milhão que eu esqueci. \\ Deixo este mundo daqui, \\ selva com lei de cassino; \\ vou renascer num menino, \\ num país além do mar... \\ Licença, que eu vou rodar \\ no carrossel do destino. \\ Enquanto eu puder viver \\ tudo o que o coração sente, \\ o tempo estará presente \\ passando sem resistir. \\ $\mathrm{Na}$ hora que eu for partir \\ para as nuvens do Divino, \\ que a viola seja o sino \\ tocando pra me guiar... \\ Licença, que eu vou rodar \\ no carrossel do destino.
}




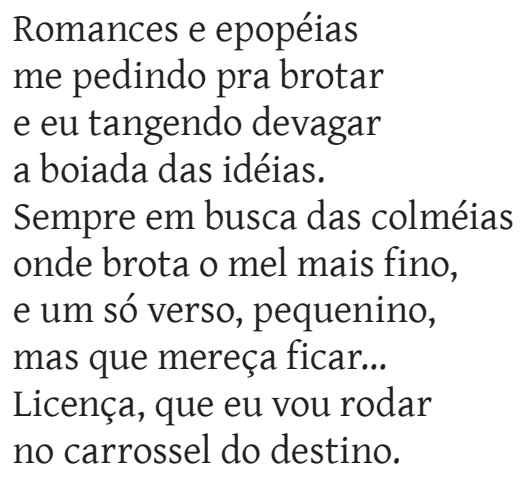

A música, de autoria de Antonio Carlos Nóbrega, em parceria com o escritor Braulio Tavares, vem escrita também em décimas de sete sílabas, ao ritmo de uma ciranda, com uma letra que trata da partida, do desprendimento, do tempo que passa e não mais volta. Fala, enfim, do que nos reserva o destino que, como um carrossel, não possibilita a ninguém saber em que ponto vai parar de girar. o carrossel do destino gira de forma diferente para cada um de nós. Cada qual com o seu tempo, cada tempo sem mais tempo para seguir.

Também numa parceria entre Nóbrega e Braulio Tavares, a música O Rei e o Palhaço, presente no disco Lunário Perpétuo, é mais um claro exemplo quanto ao uso das formas poéticas do romanceiro popular, com a utilização de algumas de suas formas tradicionais, na elaboração do trabalho poético do artista. Dessa vez, numa escrita em décimas de sete sílabas, forma utilizada tanto pelos cantadores, em seus repentes, quanto pelos mestres de Maracatu Rural ${ }^{2}$ em seus torneios poéticos.

2 Também chamado de Maracatu de Baque Solto, Maracatu de Orquestra ou, ainda, de Maracatu de Trombone, o Maracatu Rural, nomenclatura mais conhecida, tem origem incerta, com várias explicações para o seu surgimento, umas mais convincentes, outras mais fabulosas. Mas, todas as versões apontam para a mistura das culturas afro-indígenas como 
Sua coroa é de ouro, o meu chapéu é de palha.

A sua cota é de malha, o meu gibão é de couro.

Sua justiça é no foro, minha lei é o consenso. O seu reinado é imenso, minha casa é meu país. Você é preso ao que diz, eu digo tudo o que penso.

Você vem com a arma erguida, eu vou abaixando a guarda. Você vem vestindo a farda, eu de roupa colorida. Você disputa corrida, eu corro pra relaxar. Sua marcha é militar, a minha é de Carnaval. Seu traje é de general, eu visto pena e cocar.

Você liga a motosserra, eu planto flor no cerrado. Você só anda calçado, eu piso com o pé na terra. Você quer vencer a guerra, eu quero ganhar a paz. Você busca sempre mais, eu só quero o que é meu. Você se acha europeu, eu sou dos canaviais. 


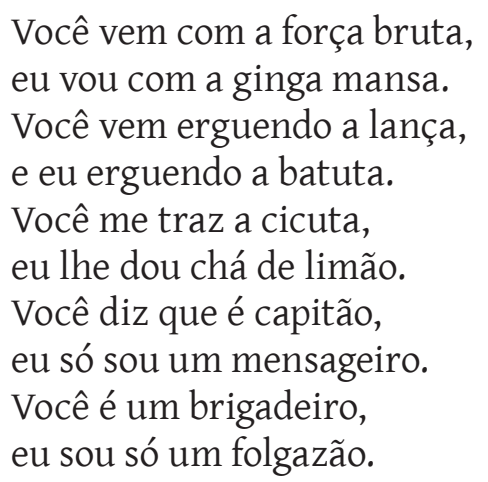

Ao som do Maracatu Rural nos é apresentado nessa música dois mundos bem diferentes. O mundo do "rei", com leis e regras a serem seguidas e obedecidas, antecedendo as conquistas pela força, guerra, poderio bélico, entre outros elementos. Tais aspectos vêm evidenciados, por exemplo, nas frases "você vem com a arma erguida", "você vem vestindo a farda", "você disputa a corrida", "você quer vencer a guerra", "você vem com a força bruta" e "você vem erguendo a lança", ou seja, um mundo de disputas e imposições aos menos favorecidos.

Ao "palhaço", representado aí pela grande parcela da população, os mais frágeis, são atribuídas qualidades vinculadas ao popular, como os próprios elementos expostos, a exemplo do chapéu de palha, do chá de limão, gibão de couro e o próprio festejo do carnaval. Ao longo do poema, o "palhaço" pode ser um homem do campo ou um trabalhador dos canaviais. Pode ser, ainda, um folgazão ou mesmo um índio, usando pena e cocar.

Perspectivas diversas podem ser apontadas ao longo da música, como, por exemplo, a própria lição de vida que é dada a cada resposta do "palhaço". Se o "rei" disputa a corrida, o "palhaço" corre para relaxar; se o "rei" liga a motosserra, o "palhaço" planta flor no cerrado; se o "rei" quer vencer a guerra, ao "palhaço" interessa ganhar a paz; e, por fim, se o "rei" ergue 
a lança, o "palhaço" ergue a batuta para reger uma orquestra sem desafinados, uma orquestra de alegrias e belos acordes que soa bem aos ouvidos dos tantos outros "palhaços" presentes na plateia de um único espetáculo.

A música 0 Rei e o Palhaço traz, ainda, uma outra perspectiva a ser observada em relação ao todo da produção de Antonio Carlos Nóbrega. A presença da temática reino é recorrente na sua produção, o que não deixa de ser, também, uma herança do romanceiro popular nordestino, já que essa temática encontra uma forte ligação com a tradição popular. "Nos folhetos de cordel, as fazendas são quase sempre reinos, e os fazendeiros são reis, condes, duques ou barões. Suas filhas são princesas, e os vaqueiros e cangaceiros são quase sempre os cavaleiros desses reinos imaginados pelos poetas populares" (NEWTON JÚNIOR, 1999, p. 210).

Como foi visto anteriormente, esse aspecto vem bem presente, também, na obra do criador do Movimento Armorial. É o caso dessa passagem no Romance d'A Pedra do Reino, quando Quaderna afirma sobre seu próprio reino:

Seria um Reino literário, poderoso e sertanejo, um Marco, uma Obra cheia de estradas empoeiradas, caatingas e tabuleiros espinhosos, serras e serrotes pedreguentos, cruzada por Vaqueiros e Cangaceiros, que disputavam belas mulheres, montados a cavalos e vestidos de armaduras de couro. Um Reino varrido a cada instante pelo sopro sangrento do infortuíto, dos amores desventurados, poéticos e sensuais, e, ao mesmo tempo, pelo risco violento e desembandeirado, pelo pipocar dos rifles estralando guerras, vinditas e emboscadas, ao tropel dos cascos de cavalo, tudo isso batido pelas duas ventanias guerreiras 
do Sertão: o cariri, vento frio e áspero das noites de serra, e o espinhara, o vento queimoso e abrasador das tardes incendiadas. (SUASSUNA, 2005, p. 115).

No trabalho de Nóbrega, a temática reino está presente em nove músicas que tratam direto ou indiretamente desse aspecto. Além da já citada O Rei e o Palhaço, são elas: Boi Castanho, O Romance de Clara Menina com D. Carlos de Alencar, Pernambuco Falando para o mundo, Quinto Império, Estrela D’Alva, Romance da Filha do Imperador do Brasil, Lunário Perpétuo e a música Excelência.

Juntamente ao uso dessas formas poéticas do romanceiro popular nordestino está a perspectiva Armorial de trabalhar com a recriação ou reelaboração de temáticas extraídas das manifestações populares do Nordeste, como já foi verificado em diversas ocasiões do presente estudo. Essa concepção também vem evidenciada de forma bastante significativa nos trabalhos de Antonio Carlos Nóbrega.

O caso do poema A Morte do Touro Mão de Pau é bem sugestivo para melhor identificarmos esses elementos. De autoria de Ariano Suassuna, inspirado no folheto O Boi Mão de Pau, do poeta rabequeiro rio-grandense-do-norte Fabião Hermenegildo Ferreira da Rocha (1848-1928), conhecido por Fabião das Queimadas, o poema foi posteriormente musicado por Nóbrega, no disco Lunário Perpétuo. Além de ter sua temática extraída do romanceiro, sendo escrita em sextilhas heptassilábicas de rimas simples, com a presença de rimas toantes, o poema foi reelaborado pelo escritor Ariano Suassuna, em memória de seu pai, João Suassuna.

A história trata de um boi brabo e da sua luta pela vida, numa fuga constante de vaqueiros que tentam, em vão, capturá-lo. Numa dessas perseguições, o Mão de Pau, para não ser apanhado e humilhado por vaqueiros, atira-se de um penhasco 
e se despede da vida de forma honrosa. O romance está implicitamente ligado aos momentos finais de vida do pai de Ariano Suassuna, João Suassuna, que apesar de não ter se suicidado como fez o Mão de Pau, vivenciou um conflito semelhante entre a possibilidade de desonra e da morte, e mesmo sabendo do risco que corria pelas ameaças que recebia, não hesitou em ir ao Rio de Janeiro para se defender na Câmara dos Deputados da acusação de cúmplice do assassinato de João Pessoa. No Romance do Boi da Mão de Pau, o boi-narrador cita vários nomes de vaqueiros que tentaram capturá-lo. Entre esses, um chamado Miguel e outro Antônio Rodrigues, mesmos nomes do assassino do seu pai e do contratante de sua morte, respectivamente.

$\mathrm{Na}$ versão do poeta popular, predomina o aspecto mais rural, com o Mão de Pau narrando suas 'escapadas' diante de vaqueiros que vinham de toda parte tentando capturá-lo. Apesar de sempre conseguir escapar, o Mão de Pau já demonstrava sua insatisfação com a necessidade de viver se escondendo e fugindo dos vaqueiros e seus cavalos, como podemos ver nesse trecho adiante:
$[\ldots]$
Me caçaram muito tempo,
ficaram desenganado
E eu agora de-meu,
lá na serra descansado.
Acabo de muito tempo
vi-me muito agoniado.
Quando foi com quatro mês, um droga dum caçadô, andando lá pulos matos, lá na serra me avistou, correu depressa pra casa dando parte a meu sinhô. 
Foi dizê a meu sinhô

- Eu vi Mão de Pau na serra.

Daí em diante os vaqueiro, pegaro a mi fazê guerra.

Eu não sei que hei de fazê para vivê nesta terra.

Na versão de Suassuna, o poema acentua seu tom mais trágico, com a narrativa em terceira pessoa, contada com maior riqueza de detalhes no que se refere ao aspecto físico do animal, que já não resiste às perseguições dos inúmeros vaqueiros que estão na busca de sua captura. Nessa versão, não existe relato algum da vida do animal, qualquer tipo de descrição de fatos de sua vida, que não seja a imediata perseguição pelos vaqueiros e seus cavalos. Vejamos a seguir o início dessa versão do poema:

Corre a Serra Joana Gomes

galope desesperado:

um touro se defendendo, homens querendo humilhá-lo, um touro com sua vida, os homens em seus Cavalos.

Cortava o gume das Pedras um bramido angustiado, se quebrava nas Catingas um Galope surdo e pardo e os Cascos pretos soavam nas pedras de Fogo alado, enquanto o clarim da Morte, ao Vento seco e queimado, na poeira avermelhada envolvia os velhos Cardos. 


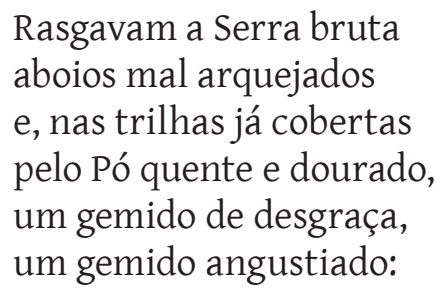

Ao contrário da versão original, quando existe um relato anterior acerca da vida e fama do Mão de Pau, Suassuna narra os momentos finais vividos pelo animal, quando numa dessas perseguições, não vendo mais saída, o Mão de Pau sobe a Serra Joana Gomes e de lá não sai mais com vida. A narrativa nesse momento ganha em carga dramática, uma vez que é nessa mesma Serra que ele nasce e é criado. A Serra Joana Gomes passa a ser testemunha ocular da tragédia que marca a vida do Mão de Pau desde o seu nascimento até os momentos finais da sua vida. Ali ele nasceu, viveu e não teve outra escolha que não fosse a escalada até um penhasco se jogando do alto. Um salto para a morte, justificado pela honra.

\author{
Num grito, todos pararam, \\ pelo horror paralisados, \\ pois sempre, ao rebanho, espanta \\ que um touro do nosso Gado \\ às teias da Fama-negra \\ prefira o gume do Fado. \\ E mal seus perseguidores \\ esbarravam seus Cavalos, \\ viram o Manco selvagem \\ saltar do Rochedo pardo:
}


-AAdeus, Lagoa dos Velhos!

Adeus, vazante do gado!

Adeus, Serra Joana Gomes

e cacimba do Salgado!

Assim vai-se o Touro manco,

morto mas não desonrado'!

O Mão de Pau não era um animal como os outros, fazendo com que mais vaqueiros viessem de longe com o objetivo de capturá-lo. À captura, o Mão de Pau preferiu a morte. Um desfecho trágico, mas honrado como afirma a versão de Suassuna. $\mathrm{Na}$ verdade, uma metáfora utilizada por Suassuna para falar do acontecimento histórico do dia 9 de outubro de 1930, data da morte de João Suassuna.

O processo de reelaboração da obra continua na música A Morte do Touro Mão de Pau. Nessa versão, Nóbrega alterna declamações com bandas-de-pífanos, cantoria-de-viola e aboios e proporciona um ritmo mais intenso, aumentando também a carga dramática em torno da perseguição que vai originar a morte do Mão de Pau. Temos aqui duas versões trabalhadas na perspectiva de recriação das artes, como propõe o Armorial, a partir do uso de formas poéticas do romanceiro popular. Merece destaque na versão musicada por Nóbrega o timbre de voz imposto pelo artista. Um elemento próprio dos cantadores que se caracteriza como mais um aspecto presente na tradição nordestina.

A ideia de elaboração de uma obra, a partir de trabalhos anteriores, pode vir de forma literal como foi verificado no poema A Morte do Touro Mão de Pau ou através de alguns elementos isolados dentro do contexto de uma determinada produção. É o caso do personagem Brusacã (uma das muitas formas assumidas pelo demônio) descrito por Ariano Suassuna no Folheto LVI do Romance d'A Pedra do Reino, intitulado A Visagem da Besta Brusacã. A recriação, a partir desse personagem, pode acontecer 
de forma literal, como é o caso da pintura Besta Bruzacã, de Miguel dos Santos; ou, ainda, a partir de um elemento específico dentro da obra. É o que acontece, por exemplo, na música Desassombrado, presente no disco Na Pancada do Ganzá, quando surge Bruzacã.

Na obra de Suassuna, Bruzacã surge a partir de uma descrição do personagem Quaderna para o Juiz Corregedor, depois de ser questionado sobre sua crença no diabo. Quaderna diz acreditar e descreve as características da Besta Bruzacã para o Juiz Corregedor, que afirma nunca tê-la visto:

[...] Pois eu me admiro muito, porque é a Besta mais horrorosa e conhecida por todo esse mundo velho aí afora! É coisa sabida, Sr. Corregedor: ela é o Mal, o Enigma, a Desordem! Passa no Mar os seis meses do tempo de chuva. Durante esse tempo, tem duas ocupações: causa as tempestades e fica esperando, perto da Costinha, aqui na Paraíba, a chegada das Baleias, que ela sangra e devora como se fossem traíras ou Curimatãs. Aí, quando vem chegando Setembro, ela sai do Mar, soprando fogo pelas ventas, e vem para uma Furna de pedra perdida no Sertão. O fogo soprado pela respiração dela é que faz a seca! E ela aparece com muitas formas! [...]. (SUASSUNA, 2005, p. 402).

Quaderna conta para o Juiz Corregedor a visagem do vaqueiro Manuel Inácio, que teria visto Bruzacã sair do mar, próximo à Praia de Touros, no Rio Grande do Norte, perto de meio-dia, no dia 24 de agosto de $1919^{3}$, quando viajava com um rebanho de

3 Esta data é na crença popular nordestina o dia em que o diabo anda solto pelo mundo, além de ser também o dia do nascimento do Boi 
gado que iria vender em Macau e alguns burros carregados de couros para trocar por sal para o Sertão. Segundo Quaderna, depois de parar para almoçar e descansar um pouco, enquanto os animais pastavam, Manuel Inácio observou que a terra se elevava suavemente formando um morro pedregoso que caía no mar. Deslumbrado com o fenômeno que estava por acontecer e sem saber do que se tratava, o vaqueiro começou a ouvir uns mugidos estranhos e poderosos e, de repente, via sair das profundas águas do mar a Bruzacã:

[...] Ah, só quem já viu Bruzacã é que pode imaginar como são poderosas e aterrorizantes as formas que ela toma! São sete Chifres turvos e amolados, o Focinho peludo, a Corcova cerúlea! No cabelouro espesso, uma Cabeleira de serpentes e conchas entrançadas! O olhar de Cobra e o corpo feito à semelhança de um corpo enorme de Touro branco! Era a Besta marinha, partejada pelos lombos diabólicos e sagrados do Mar! Seu olhar chamejava, ora amarelo, ora azul como um aço de Martelo! Ao fogo do sopro das suas Ventas, ferviam as águas em borbulhas de Enxofre envenenado. 0 peito era coberto pelo musgo nojento que suja e mancha as paredes do Inferno alumiado! As espáduas eram cobertas de malhas feridentas cor de ferrugem e em cada uma das suas ancas verdes luzia uma estrela amarela, brilhando entre sargaços e a salsugem, entre ostras pegadas ao tronco, anoso e velho como um velho Rochedo extraviado. (SUASSUNA, 2005, p. 406).

Mandingueiro. 


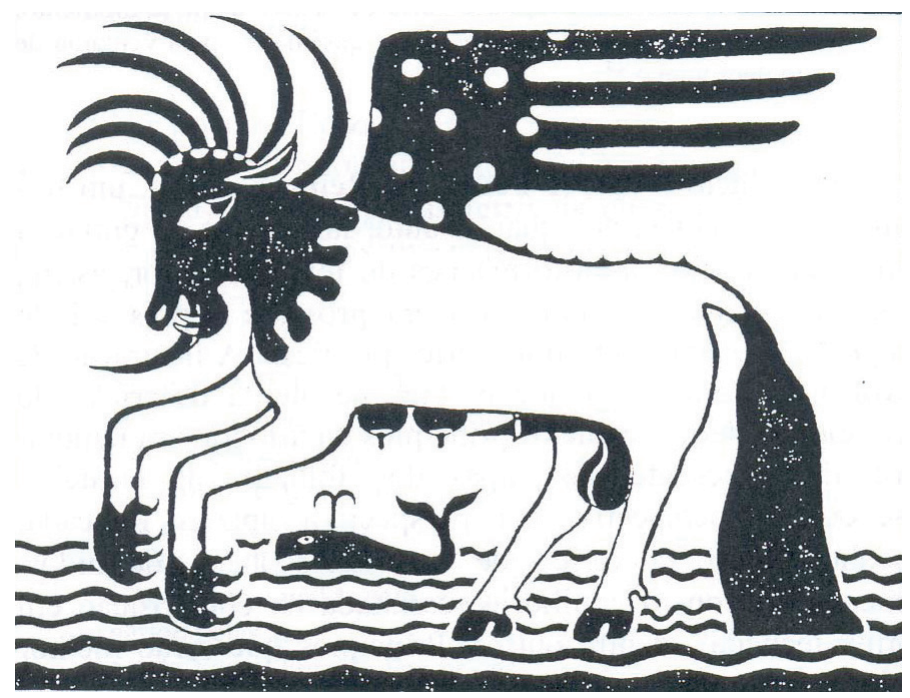

FIGURA 1 - Imagem da encarnação da Besta Bruzacã.

Vemos aí a descrição da assustadora e temida Bruzacã, uma das formas do demônio descritas na obra. Na música Desassombrado, ela surge de forma menos aterrorizante, porém não menos temida, por um personagem galopando no chitão de sua burra.

Desassombrado, eu desassombrei.

Eu pensei que o malassombro fosse maior do que eu.

Ói, meus senhores, vou contar minha odisséia:

viajei no pé da idéia prá tecer este cantar. 
E galopando

no chitão de minha burra

fiquei preso numa furna

sem poder mais cavalgar.

[...]

No outro dia,

a Brazucã me apareceu, minha alma estremeceu, eu fiquei pra me acabar.

Aí pensei:

me valei Nossa Senhora, não me leve nessa hora, ainda quero vadiar.

Ao ritmo de um xote, a música, de autoria de Nóbrega e musicada por Antônio Madureira, narra a história de um personagem que sai por aí viajando e desassombrando alguns "malassombros" e se depara com a Besta Brusacã, no resgate de um personagem presente numa outra obra Armorial, nesse caso específico 0 Romance d'A Pedra do Reino, fazendo dela apenas uma passagem dentro de uma outra obra, o que não deixa de se caracterizar como uma recriação.

Um outro aspecto presente nas letras das músicas de Antonio Carlos Nóbrega que vai tornar mais latente essa percepção do Armorial e seu reconhecimento, a partir do trabalho com elementos próprios da cultura popular, é o aspecto emblemático e simbólico. São casos em que as letras das músicas surgem como verdadeiras insígnias, repletas de elementos que transcendem o texto, com alusões a bandeiras, estandartes, agremiações dos blocos carnavalescos próprios dos períodos festivos dos contextos populares, entre outros diversos elementos que se fazem presentes. $\mathrm{Na}$ verdade, mundos distintos que se formam a 
partir da descrição textual, como podemos verificar na música Estrela D'Alva, presente no disco O Marco do Meio-Dia, de autoria de Nóbrega, em parceria com Braulio Tavares e Zezinho Pitoco:

\author{
Estrela d'Alva, \\ olha a luz do dia. \\ Estrela d'Alva, \\ olha a luz do sol. \\ Estrela d'Alva, \\ não me deixe sem meu guia. \\ Estrela d'Alva, \\ não me deixe só.
}

Caixa-de-guerra, maracá, porta-bandeira, rainha negra batendo palma de mão... Baque-virado fez tremer o chão do mundo, bomo-profundo ressoou trovão...

Ladeira acima os cortejos vão seguindo, Brasil afora vai cantando a procissão... Nos estandartes os emblemas do Divino, olhos na altura e os pés no chão.

Num mar de gente os andores navegando santos de barro e resplendores de papel, ramos e palmas verdejando a rua inteira, e a padroeira a flutuar no céu.

Anjos-meninos de olhos pretos e asas brancas, e a banda toca um hino triste e triunfal, cristãos e mouros cruzam lanças na avenida e se ajoelham frente à catedral. 
Cacos de vidro são rubis e diamantes, e cada crente nesse instante é um Jesus, cada promessa conta o drama de uma vida, e cada vida se transforma em luz.

Blocos desfilam seus calungas e brincantes, bichos gigantes, jaraguá, cobra-coral... Reis maltrapilhos vão cantando Ave Maria, e a romaria puxa o Carnaval.

Como podemos verificar, o aspecto emblemático reflete o aspecto visual da letra da música. De forma detalhada, a letra apresenta um grande cortejo, repleto de luz, cor e musicalidade que vai cortando o Brasil numa grande procissão. Na verdade, um momento de reunião entre diferentes cortejos, com maracatus, caboclinhos, chegança ${ }^{4}$, além da procissão. Todos os cortejos reunidos num único e maior momento, o carnaval, com as diversas raças e manifestações presentes e dividindo o mesmo espaço. Todos guiados pela Estrela D’Alva, guia de cada um dos "andores" no imenso "mar de gente".

Esse aspecto emblemático e simbólico que transpõe o texto pode ser verificado em outros diversos exemplos. Caso semelhante acontece com o poema Martelo D'O Marco do Meio-Dia, presente no disco 0 Marco do Meio-Dia:

4 A chegança é uma dança representativa das lutas entre cristãos e mouros no início da monarquia portuguesa. Na apresentação, formam-se dois partidos: o dos mouros, encastelados num forte construído na praia; e os cristãos, que ficam em canoas e jangadas. Depois de comunicações e discussões, os cristãos declaram guerra e os mouros saem do forte para a batalha simulada, que termina com a vitória dos cristãos, com os mouros refugiados no castelo, hasteando bandeiras brancas com a cruz vermelha da Ordem de Cristo. Ao final, o Rei Mouro é trazido à presença do Rei Cristão para ser batizado com água do mar, ao som de tambores, flautas, violas, maracás e cantos de vitórias. 


\begin{abstract}
A Bandeira do Sol estrala ao vento e soa a minha voz de Cantador, num protesto do Sonho contra a Dor, a pobreza do povo e o sofrimento. Nas estrelas do Canto, o pensamento ergue um Marco que é só anunciado. Nossa sorte de Povo injustiçado é vencida por nós ao som da luta, e, no meio do palco, o que se escuta é o sol da justiça do Sonhado.

Ao final desta Dança bela e forte sou eu o Cantador, dono da Casa, e, com versos de sangue, fogo e brasa, forjo o Marco e celebro a minha sorte. $\mathrm{Na}$ viola, eu vou batendo a Morte e assumindo a coroa de Guerreiro. Ao cantar meu país, sou o Lanceiro, olho o sangue ferido do meu povo e sonho, ao meio-dia, um Canto novo, levantando este Marco brasileiro.
\end{abstract}

De autoria de Ariano Suassuna e Antonio Carlos Nóbrega, o poema Martelo D’o Marco do Meio-Dia não é menos emblemático que o exemplo anterior. Uma descrição detalhada de um mundo que envolve sangue, fogo, brasa, brilho, sonhos, justiças, crenças e glórias de um reino que se junta ao aspecto simbólico presente no próprio texto. Duas linguagens distintas, a partir de um único elemento, mas que, reunidas, contemplam um ao outro.

Em determinado ponto, o texto poderia substituir a imagem e a imagem representar o próprio texto ou, ainda, um decifrando o outro, ampliando suas possibilidades. Essa perspectiva mais subjetiva aqui exposta poderia ser associada ao princípio da 
integração das artes que propõe o Armorial. Ou seja, nesse caso específico, ao criar um texto, o escritor lhe possibilitaria outras visões, trazendo novas perspectivas, a partir de uma primeira matriz. Uma espécie de leitura não-linear que poderia ter início num texto escrito, que se caracterizaria como a matriz inicial para em seguida, ter sequência através de uma leitura imagética, elaborada a partir da primeira e, assim, sucessivamente.

O princípio da integração entende a obra de arte pelo lado oposto. Os diversos gêneros de arte não só podem como devem se complementar, principalmente no campo das artes plásticas. Dessa forma, é perfeitamente legítima a preocupação de um escultor com a cor, ou a de um arquiteto com elementos de construção similares às cariátides gregas, que são escultura e estrutura ao mesmo tempo. (NEWTON JÚNIOR, 1999, p. 108).

Esse tipo de elaboração dos trabalhos Armoriais faz de cada obra um ponto de partida para as demais. Nesse sentido, esse princípio vai direcionar a produção das artes Armoriais para algo já mencionado e discutido amplamente ao longo desse trabalho, que diz respeito à criação, a partir de obras anteriores, enriquecendo e ampliando diferentes temas.

Como podemos verificar, esse processo é bastante presente notrabalho de Antonio Carlos Nóbrega e se faz presente, também, no seu repertório, na utilização de alguns romances de origem ibérica. Assim como o Quinteto Armorial, Nóbrega, ao longo dos seus trabalhos recitais, faz uso de alguns desses romances e loas, imprimindo não apenas o cantar, mas a interpretação dos personagens envolvidos na história. Essa sua habilidade exímia possibilita uma proximidade, uma linha tênue entre seu trabalho e o reconhecimento por parte do público. 
$\mathrm{Na}$ verdade, o ato de cantar poemas memorizados é privilégio não apenas de cantadores profissionais, mas também de pessoas, na maioria das vezes, idosas, que guardam em sua memória longos poemas, os quais recebem o nome de cantigas velhas. É o que diz o escritor Braulio Tavares ao citar o exemplo do Romance de Dona Silvana, presente parcialmente no Romance d'A Pedra do Reino.

'Romanceiras' ou 'cantadeiras' como Donana existem em grande número ainda hoje, trazendo na memória dezenas de romances obscuros, alguns deles com séculos de existência, passados de geração em geração, de voz em voz, de memória em memória. São o fluxo ainda vivo de uma cultura oral em que essas histórias são contadas e recontadas muitas vezes, perpetuando-se. Na passagem de uma pessoa para outra o texto sofre perdas, alterações, acréscimos, mas a natureza peculiar dessa literatura faz com que tais modificações não sejam vistas como erros, mas como variantes. No universo dos romances orais não existe uma versão correta e versões erradas. $O$ romance é a soma conjunta de todas as suas versões. (TAVARES, 2007, p. 30).

Como foi visto no primeiro capítulo, tal aspecto é possibilitado pela memória, aspecto importante da narrativa e elemento bastante presente na elaboração das artes populares, constituindo-se na formação de uma identidade social, que influencia diretamente nas interpretações apresentadas, a partir dos grupos e pensamentos a eles pertencentes, nos quais os indivíduos estão inseridos. 
Enquanto representação, a Memória permite que se possa lembrar sem a presença de coisa ou de pessoa evocada, simplesmente com a presença de uma imagem no espírito e com o registro de uma ausência dada pela passagem do tempo. [...] O final desse processo de rememoração seria dado pelo reconhecimento, por aquele que rememora, da certeza do acontecido: foi ele, foi lá, foi então, foi assim. O reconhecimento se opera por um ato de confiança, que confere veracidade à rememoração. (PESAVENTO, 2003, p. 94-95).

Nos trabalhos recitais de Antonio Carlos Nóbrega, identificamos alguns casos, a exemplo dos títulos Minervina, o Romance de Clara Menina com D. Carlos de Alencar, Romance da Nau Catarineta e o Romance da Filha do Imperador do Brasil. Todos esses, assim como outros tantos exemplos dentro do trabalho do artista, passaram por esse processo de apropriação, cabendo à memória a manutenção dessas características que embora preservadas e, portanto, vivas, mantêm-se no anonimato.

No caso da música Minervina, de autoria de Nóbrega, em parceria com Marcelo Varella, presente nos discos Na Pancada do Ganzá e Pernambuco Falando Para o Mundo, trata-se de uma versão do romance de mesmo nome, de origem ibérica, que veio para o Brasil no século XVII e que ainda é encontrado na região nordestina. Sua letra faz menção à personagem Minervina, que é apresentada como fêmea fogosa, dona de um voraz apetite sexual.

Quem nunca viu amor assim tão roxo... vai fazer fuxico quando ver Minervina. Desvergonhada, não conhece alvoroço, na hora $\mathrm{H}$ é minha estrela matutina. 


\author{
É minzinguenta quando vai prá brincadeira. \\ Não dá bandeira na hora da cavilação. \\ É majestosa, topa tudo a noite inteira, \\ Quando me arrocha faz das tripas coração. \\ Ô Minervina! Ô Minervina! \\ Rebola-bola no consolo \\ das meninas.
}

Os títulos Romance da Nau Catarineta e Romance da Filha do Imperador do Brasil, ambos presentes no disco Lunário Perpétuo, estão presentes no Romance d'A Pedra do Reino e o príncipe do sangue do vai-e-volta, e seguem a proposta Armorial de recriação a partir de obras anteriores. Nas duas músicas, Nóbrega representa diversos personagens, atribuindo-lhes vozes peculiares.

Na versão presente no Romance d'A Pedra do Reino e o príncipe do sangue do vai-e-volta, o Romance da Nau Catarineta aparece no folheto XXXIV, intitulado Marítima Odisséia de um Fidalgo Brasileiro, num diálogo entre Quaderna, Samuel e Clemente. Incentivado pelas ideias de Quaderna, Samuel começa a relatar vários trechos da crônica seiscentista de Frei Vicente do Salvador sobre Duarte de Albuquerque Coelho e Jorge de Albuquerque Coelho, filhos de Duarte Coelho.

Em um dado momento, Samuel fala de uma nau brasileira, sob o comando de Jorge de Albuquerque Coelho, que já estaria sem nenhum tipo de mantimento, pois os franceses teriam deixado apenas "dois sacos de biscoitos podres, "uma pouca de cerveja danada', duas canadas de vinho, um frasco de água-deflor, alguns cocos, poucos punhados de farinha e seis tassalhos de peixe-boi" (SUASSUNA, 2005, p. 218). Por mais que Jorge de Albuquerque tivesse o cuidado de dividir bem a pouca comida restante entre os tripulantes, com o passar do tempo, a marujada começou a ficar faminta, chegando ao desespero de "deitar 
sortes", para escolher um dos homens da nau a ser morto, servindo de comida para os outros tripulantes. Nesse momento, o personagem protagonista Quaderna associa a história contada por Samuel à História da Nau Catarinet ${ }^{5}$, romance de origem ibérica, cantado no Sertão nordestino, fazendo parte do Fandango, uma tradicional dança em pares presente no Nordeste brasileiro, originada em Portugal e Espanha.

O tradicional romance é apresentado por Nóbrega como fandango ou marujada ${ }^{6}$. Com suas toadas populares, as melodias presentes no disco são as mesmas que foram utilizadas por Antônio José Madureira, numa versão instrumental escrita para o Quinteto Armorial.

Nessa versão, Nóbrega mantém o diálogo constante entre o Capitão-General e o Gajeiro durante quase toda a execução da música. Ao final, surge um terceiro personagem, o demônio. Cada um dos personagens recebe um tratamento diferenciado por Nóbrega, que incorpora características para cada um deles, através da sua interpretação.

5 A História da Nau Catarineta narra a história de uma nau que há mais de um ano vagava pelo mar. Já não tendo mantimentos, a tripulação "deita sorte" a uns dos companheiros de bordo para que servisse de alimento, que acabaria sendo o Capitão-General. Não querendo se entregar, o Capitão-General insiste na possibilidade de salvação, pedindo ao Gajeiro que suba até o mastro real para ver "terras de Espanha e areias de Portugal". Depois de prometer o que podia em troca da vida, o CapitãoGeneral descobre que ali estava o Diabo, tentando a tripulação, e a única coisa que o interessava era a alma do Capitão. Não aceitando se entregar ao Demônio, o Capitão se joga ao mar, mas um anjo o toma nos braços, salvando sua vida e a tripulação que consegue chegar ao Porto do Mar.

6 Trata-se de uma simulação de combate naval inspirado na história da Nau Catarineta ou outra qualquer tragédia acontecida no mar. Os principais personagens são: Capitão-General, Capitão, Piloto, Imediato, Médico, Mestre, Contra-Mestre, vinte e quatro marujos, Gageiro e Calafate. 
O mesmo acontece com o Romance da Filha do Imperador do Brasil. Recriado por Ariano Suassuna, o romance se passa num contexto sertanejo, tendo como personagens o Imperador Dom Pedro, a Infanta, a Criada e o Vaqueiro. Cada um desses personagens recebe um tratamento diferenciado na versão musicada por Nóbrega, que explora suas qualidades ao som de um xote, com as presenças marcantes do acordeom, triângulo, zabumba, pandeiro e violão. Dessa forma, atribui vozes características para cada personagem, com destaque para o tom debochado em falsete, utilizado para interpretar a voz da Infanta, de modo zombeteiro.

A história narra uma situação vivida pela Infanta, filha do Imperador Dom Pedro, que se apaixona por um Vaqueiro:
O Imperador Dom Pedro
tem uma Filha bastarda, a quem quer tanto do bem
que ela ficou malcriada!
Queriam casar com ela
Barões de capa e de espada.
Ela, porém, orgulhosa,
a todos que recusava:
- Este, é menino! Esse é velho!
Aquele, lá, não tem barba!
O de cá, não tem bom pulso
Pra manejar uma Espada!
Dom Pedro falou, se rindo:
- Inda serás castigada!
Não vás tu, de algum Vaqueiro,
terminar apaixonada!

E mesmo com os cuidados e orientações do Imperador, a Infanta acaba se apaixonando por um Vaqueiro. $O$ fato acontece na madrugada, quando, da janela, ela observa passar três 
moradores que trabalhavam de enxada. Um deles, o que mais trabalhava, chama atenção da princesa que pede para a Criada levá-lo até ela.

$[. .$.

- Senhora, o que é que me manda?

Eu vim por vossa chamada!

- Quero saber se te atreves

a queimar minha Coivara!

- Atrever, me atrevo a tudo,

que um homem não se acovarda!

Dizei-me, porém, Senhora, onde está vossa Coivara!

- É abaixo dos dois Montes,

na Fonte das minhas águas,

abaixo do Tabuleiro

e na Furna da Pintada,

na linha da Perseguida,

no corte da Desejada!

Passam o dia folgando,

o mais da noite passavam,

e o Vaqueiro socavando:

ele sabe o que cavava!

À meia-noite, a Princesa

pediu tréguas, por cansada:

- Basta! Basta, meu Vaqueiro!

Queimaste mesmo a Coivara!

Não sei se por varas morro

ou com ela incendiada!

E, assim, a filha do Rei

do orgulho foi castigada! 
No Romance d'A Pedra do Reino, o Romance da Filh a do Imperador do Brasil surge depois de um diálogo entre o personagem Quaderna e seu padrinho João Melchíades. Inicialmente, o padrinho conta para Quaderna os tipos principais de romances versados. "[...] os romances de amor; os cangaceiros e cavalarianos; os de exemplo; os de espertezas, estradeirices e quengadas; os jornaleiros; os de profecia e assombração; e os de safadeza e putaria" (SUASSUNA, 2005, p. 94). Em seguida, ele conta o romance, que foi avaliado por Quaderna como sendo "uma espécie de mistura de romance de amor com romance de putaria".

Já O Romance de Clara Menina com D. Carlos de Alencar, que consta no disco Na Pancada do Ganzá, é uma das muitas versões ibéricas e brasileiras existentes, sendo, também, diversos os títulos. Na recriação musical, como informa o encarte do disco, Nóbrega interpreta os quatro personagens centrais da história: Clara Menina, o Caçador, o Dom Carlos de Alencar e o Rei.

Comparada a uma outra versão coletada por Pereira da Costa, intitulada Clara Linda, que consta no estudo Os Romances da Tradição Ibérica na Obra Midiática de Antonio Carlos Nóbrega, do pesquisador Roberto Benjamin, observa-se que são poucas as alterações entre uma e outra. A versão de Nóbrega explora a narrativa por um viés mais picaresco, algo mais explícito, mas não menos insinuante do que a outra versão, como podemos verificar em alguns trechos do poema.

\author{
Estava Clara Menina \\ com D. Carlos, a brincar, \\ nua da cintura prá cima, \\ nua da cintura prá baixo, \\ namoro pra se casar! \\ Mas passou um caçador \\ que não devia passar...
}




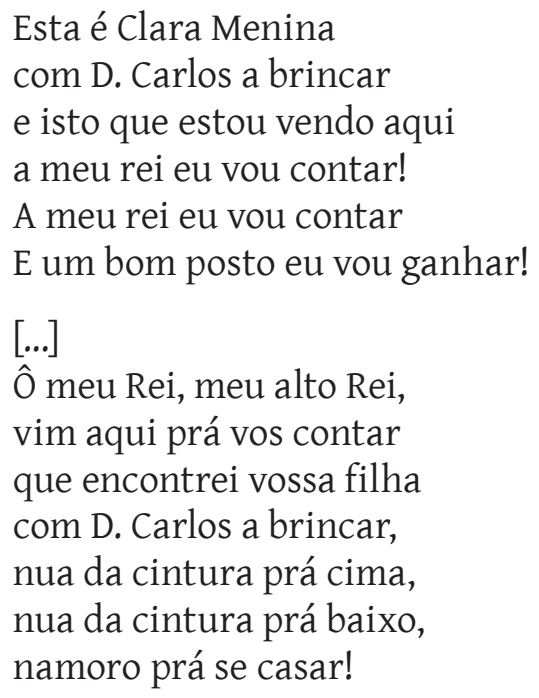

A situação é a mesma na versão a seguir, talvez explorada de maneira um pouco mais sublime, mas que não leva a uma outra interpretação que não seja a evidenciada anteriormente. Na versão coletada por Pereira da Costa, mudam os personagens, com D. Carlos de Alencar tornando-se Felizardo e, como o próprio título sugere, Clara Linda ao invés de Clara Menina.

Estava Clara Linda com Felizardo a brincar, debaixo de um arvoredo, num formoso roseiral; a um vassalo que passava, e todos os passos viu dar, Felizardo pediu logo que a el-rei não vá contar.<smiles>[CH]1CCC1</smiles>

Deus vos salve, senhor Rei, e vossa coroa real; 


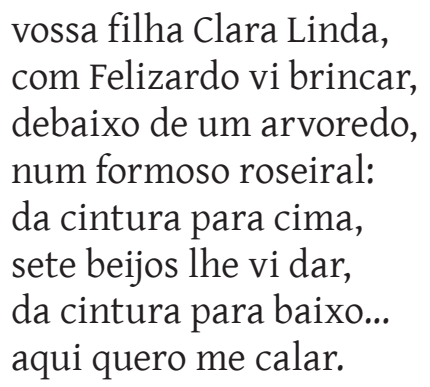

$\mathrm{Na}$ recriação musical, ao som de uma cantoria de viola, Antonio Nóbrega interpreta mais uma vez cada um dos personagens, acrescentando assim mais um elemento ao texto inicial. $\mathrm{Na}$ sua interpretação, ganha destaque a presença do personagem Tonheta, na figura do Caçador, com seu modo bem singular de se manifestar, provocando um ar de graça e trapalhada em meio à desgraça em que se mete, ao fazer a "fofoca" para o rei do namoro da sua filha com D. Carlos de Alencar:

Tu fizeste muito mal

em aqui isso contar, na frente de todo mundo, pra todo mundo escutar! Devias ter me chamado para um particular!

Eu estava só brincando quando disso vim falar! Não era Dona Clara menina nem D. Carlos de Alencar! Ela estava bem vestida, lá na igreja, a rezar!

Personagem brincante fixo de Antonio Carlos Nóbrega nos seus espetáculos, a mais recente aparição do Tonheta nos trabalhos recitais do artista foi no Lunário Perpétuo. Ele surge 
claramente na já citada canção Meu Foguete Brasileiro. Numa composição do poeta paraibano Braulio Tavares e música de Nóbrega, a obra narra as façanhas picarescas tonhetânicas a bordo de um foguete.

Eu fiz um foguete de andar pelo espaço, igual um que eu vi pela televisão: não sei se era coisa da França ou Japão, mas basta ver gringo fazer, eu já faço!... Mandei buscar logo cem chapas de aço, latão, alumínio, ferro de soldar; dez mil arrebites para reforçar a parte de fora da infra-estrutura: cem metros de longo, trinta de largura, e dez de galope voando no ar.

Botei no foguete diversas antenas para captar raios infravermelhos. Na parte de cima, um sistema de espelhos que amplia as imagens de estrelas pequenas. Motores na popa que servem apenas pra tudo aquecer, e pra refrigerar. Movidos a pura energia solar tem computadores, TVs virtuais: mil inteligências artificiais que cantam galope, voando no ar!

[...]

Depois de sentado no meu tamborete, puxei a lavanca, pisei no pedal, subi pro espaço com força total, fazendo tremer o motor do foguete. Passei bem por cima do Empire State, da torre eiffel, e do palomar; e vi pela tela se distanciar 
a mancha azulada do nosso planeta...

Pensei: 'Minha Nossa! Aqui vai Tonheta, cantando galope, e voando no ar!'.

[...]

Foi tanta Viagem, foi tanta Aventura, foi tanta Demanda, foi tanta Odisséia... eu posso jurar à distinta platéia que tudo isso foi a verdade mais pura. Também teve um pouco de literatura, história inventada para relaxar; mas eu que não minto não quero falar, e o resto eu só conto aqui pra você no próximo show, ou em outro CD, cantando galope e voando no ar...

Para poder realizar a viagem fantástica, o personagem Tonheta constrói um foguete "de mil inteligências artificiais", com recursos "ultra-modernos" para levar alguns produtos para exportação. Produtos populares de uso diversos, como, por exemplo, "saca de açúcar, tonel de carvão, baú de café, tora de madeira"; e outros made in Nordeste, diga-se de passagem. Com o foguete bem carregado de produtos genuínos, prontos para serem comercializados e utilizados durante a longa odisseia, Tonheta "puxa" a "lavanca", "pisa" no pedal e parte para o espaço com "força total", onde conhece lugares diferentes e inimagináveis, que não poderiam ser visitados de uma outra forma, que não fosse numa viagem lúdica dessa natureza, na forma de galope à beira-mar, ao som de um maracatu.

O Tonheta é um personagem de base popular, e muitas histórias e casos dele são recorrentes e fazem parte do imaginário coletivo, seja através do picaresco de histórias de Pedro Malazarte, de Cancão de Fogo, 
ou em histórias presentes no bumba-meuboi, ou através de histórias minhas que fui relembrando. [...] Ele é meu Macunaíma, sem dúvida. Idealizei uma pátria, uma genealogia para ele. Criei dois atores ambulantes que contam a história daquele personagem. Elaborei um ambiente cenográfico: esses atores ambulantes vão pelo meio do mundo com um circo mambembe - um pano de roda, que é o circo mais pobre que existe, sem cumeeira. São atores que não têm uma visão 'erudita' do teatro e se valem, pra contar essa história, apenas de seus recursos. No Segundas histórias, por exemplo, eu fazia uma paródia: Tonheta cantava homenageando a sua amada, e faz uma recriação de uma ária de Rossine; isto é, são coisas de mentalidade popular, escutar coisas assim e reelaborá-las. (NÓBREGA apud CADENGUE, 1999, p. 54-55).

Para Suassuna (apud CADENGUE, 1999, p. 53), Tonheta representa as referências vividas pelo público e, portanto, faz parte do imaginário coletivo. "Tonheta é o Brasil se revelando. [...] Tem um ditado que diz: triste é o filho que não vê o pai ir adiante. Eu digo de forma diferente: triste é o pai que não vê seu filho ir adiante. Só um ator de gênio é capaz de fazer um espetáculo e uma performance como Nóbrega em Figural".

Sendo o personagem Tonheta uma espécie de símbolo da reunião de aspectos distintos que se propagam na realidade brasileira, mais especificamente, na nordestina, com experiências vivenciadas ou referências presentes no imaginário coletivo, é notório o reconhecimento que existe por parte do público, seja ele mais erudito ou popular. É através desses sucessivos "curto-circuitos" protagonizados pelo personagem ou pela 
grande diversidade de elementos presentes no todo da sua obra, incluindo a música, o canto, a dança, a interpretação, a mímica, o instrumentista, o bonequeiro e malabarista dos espetáculos circenses, que Nóbrega possibilita essa realimentação de práticas que, apesar de não mais fazerem parte do cotidiano da maioria das pessoas, estão presentes, seja de forma mais latente, ou em grande parte das vezes, de forma mais superficial, quase que inconsciente.

Vejamos então os casos das excelências, representadas no trabalho do artista na música Excelência, presente no disco Lunário Perpétuo. A obra é uma recriação literária de Ariano Suassuna, com as toadas populares, que foi musicada por Nóbrega, a partir de uma primeira versão do Quinteto Armorial. Na versão de Nóbrega, o louvor à Virgem Maria é dividido em duas partes, sendo a primeira em forma de lamento e a segunda em forma de $A B C$, como podemos verificar no trecho a seguir:

Uma excelência da Virgem,

Oh, mãe de Deus, rogai por ele, Mãe de Deus.

Mãe de Deus, Mãe de Deus.

Oh, Mãe de Deus, rogai por ele, Mãe de Deus.

Mãe de Deus, Mãe de Deus.

Oh, Mãe de Deus, rogai a Deus por ele.

Diz o A ... Ave Maria

Diz o B ... Brandosa e Bela

Diz o C ... Cofrim da Graça

Diz o D ... Divina Estrela

Diz o E ... Esperança Nossa

Diz o F ... Fonte de Amor

Diz o G ... Guia do Povo

Diz o H ... Honesta Flor 

Diz o I ... Incenso d'Alma
Diz o J ... Jóia Mimosa
Diz o K ... Coro dos Anjos
Diz o L ... Luz Formosa

A excelência é um canto de recomendação das almas, uma espécie de ritual fúnebre, com benditos e frases apenas rimadas, ainda muito cantado no meio rural nordestino, principalmente em Pernambuco, Paraíba e no Rio Grande do Norte, sendo uma prática ainda existente e presente na vida dos sertenejos dessas localidades, que celebram sua revificação. Também chamadas de incelências ou incelenças, trata-se de uma prática do catolicismo popular, igualmente cantadas em Portugal, nas regiões de Douro e Minho, das mais antigas regiões do país, com uma cultura rica no folclore minhoto ${ }^{7}$ que se realça nas festas e romarias. Sem deixar de mencionar a existência de certos romances de origem bíblica, cantados no Marrocos, que assim como as excelências, não podem ser interrompidos e apresentam algumas características semelhantes.

Chamamos atenção para um outro aspecto bem presente na discografia de Antonio Carlos Nóbrega, que diz respeito à recorrência de algumas temáticas, como, por exemplo, aspectos relativos a história. Na verdade, temas que descrevem aspectos que dizem respeito à formação do povo brasileiro, sem deixar de mencionar figuras presentes na história do descobrimento, como os colonizadores e colonizados, além de outros episódios da história do Brasil, como o arraial de Canudos e o líder Antônio Conselheiro; e os quilombos, com a presença de Zumbi, como podemos ver a seguir:

7 O folclore minhoto é bem conhecido em Portugal pelas suas danças tradicionais, como, por exemplo, os viras, cana verdes e chulas. 
Zumbi, um negro, respirando rebeldia, foge pra mata um dia à procura do Lugar. Era um Quilombo, a terra dos ex-escravos, todos livres, sem os travos, sem ter dono pra ferrar.

Vinham mestiços, índios chegavam do eito, todos lá tinham direito, preto, branco, sarará. Uma nação de iguais sem oprimidos, de homens livres e nascidos, crescidos sem apanhar.

O sol, o sol lá vem.

Eu namoro uma morena, que sou moreno também.

[...]

Uma cruzada

contra os povos livres, bravos, para mantê-los escravos, correram então a formar. E a batalha derradeira aconteceu, jamais dela se esqueceu quem nasceu nesse lugar. 

$[\ldots]$
Primeiro sonho
brasileiro, de igualdade,
fraterno, de liberdade,
ali veio se acabar.
Mas foi semente
e deixou ensinamento
que ainda está em tempo
de viver pra se sonhar.

Ao som de um maracatu, Nóbrega e Wilson Freire descrevem um fato histórico relativo ao Quilombo dos Palmares e a morte do seu líder, Zumbi, com os personagens reais dessa história, a exemplo do bandeirante Domingos Jorge Velho, líder do grupo que destruiu o Quilombo; e o próprio acontecimento histórico em si, descrito na música como o "primeiro sonho brasileiro de igualdade, fraterno, de liberdade".

Além da música Zumbi, identificamos como temáticas históricas as seguintes músicas: Truléu da Marieta, Truléu, léu, léu, léu, léu; Canudos, Chegança, Quinto Império, Olodumaré, Nau, Romance do Aleijadinho, Galope Beira-Mar para o Bispo do Rosário, Romance da Filha do Imperador do Brasil e, finalmente, Romance de Riobaldo e Diadorim. As músicas Chegança e Olodumaré estão presentes em dois trabalhos recitais do artista, o disco Madeira que cupim não rói e Pernambuco Falando para o Mundo. A música Nau, composta por Antonio José Madureira no ano de 1989, presente no disco o Marco do Meio-Dia, mesmo sendo instrumental, foi incluída nesse núcleo temático por ser dedicada à figura do português colonizador. Dentro desse núcleo temático, pode ser observado um número maior relativo aos temas que tratam diretamente do descobrimento do Brasil, como acontece nas músicas Quinto 
Império, Olodumaré, Nau e Chegança; essa última apresentada no exemplo abaixo:

\author{
Sou Pataxó, \\ sou Xavante e Cariri, \\ Ianomami, sou Tupi \\ Guarani, sou Carajá. \\ Sou Pancaruru, \\ Carijó, Tupinajé, \\ Potiguar, sou Caeté, \\ Ful-ni-ô, Tupinambá. \\ Depois que os mares \\ dividiram os continentes, \\ quis ver terras diferentes. \\ Eu pensei: 'vou procurar \\ um mundo novo, \\ lá depois do horizonte, \\ levo a rede balançante \\ pra no sol me espreguiçar'. \\ Eu atraquei \\ num porto muito seguro, \\ céu azul, paz e ar puro... \\ botei as pernas pro ar. \\ Logo sonhei \\ que estava no paraíso, \\ onde nem era preciso \\ dormir para se sonhar.
}




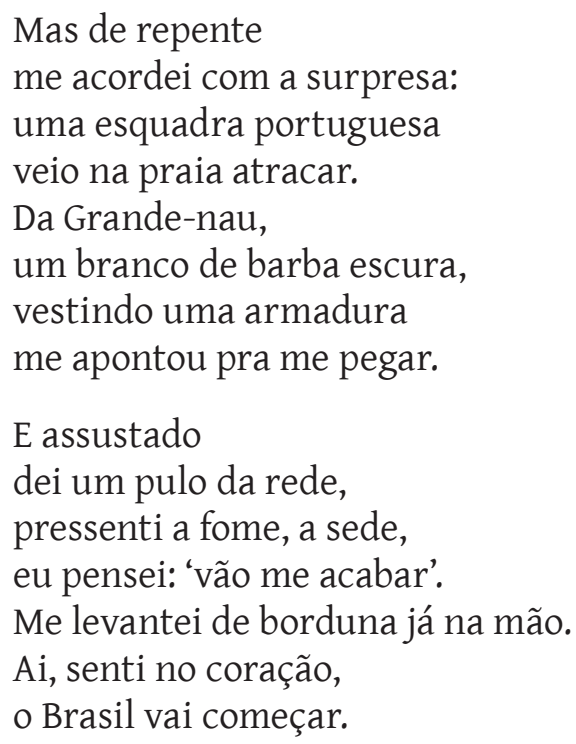

Mais uma parceria entre Antonio Carlos Nóbrega e Wilson Freire, Chegança fala da chegada dos portugueses e do começo da colonização. Logo no início, surgem algumas das tribos indígenas que habitaram o Brasil antes da chegada dos portugueses. Esse mesmo trecho acompanha toda a execução da música num refrão que se repete ao final de cada uma das estrofes. Ao som de um caboclinho, o personagem indígena narrador fala da vida tranquila e descreve a chegada da esquadra portuguesa. E com sua chegada, ele pressente e anuncia: "O Brasil vai começar".

Um outro núcleo narrativo significativo presente na discografia de Nóbrega diz respeito ao Nordeste. São músicas que falam, de alguma forma, da saga do homem nordestino, da situação do sertanejo na busca de uma situação de vida melhor fora do seu local de origem. É o caso da música Andarilho, de autoria de Dalton Vogeler e Orlando Silveira, gravada por Nóbrega no disco Madeira que cupim não rói: 
Caí do céu por descuido, se tenho pai, não sei não. Venho de longe, seu moço, lugar chamado sertão. Vivo sozinho no mundo, zombei da sede, zombei.

Cortei com a minha peixeira todo o mal que encontrei.

Fui caminhando, enfrentando as terras que o sol secou, até chegar à cidade dos homens que Deus olhou. Que o santo padre perdoe a triste comparação: melhor viver no cangaço que na tal civilização.

Brinquei com o mal, brinquei, sorri quando matei. Eu vim pra ser melhor, cheguei aqui, chorei.

A música, executada por Nóbrega no ritmo do baião, fala da saída de um retirante, o "Andarilho", que ao chegar à cidade "dos homens que Deus olhou" se depara com uma realidade ainda mais dura, a da civilização e dos seus excluídos. A letra parece ainda uma confissão do "Andarilho" ao "Santo Padre" da sua peregrinação, com sua história de vida, seus anseios quanto ao novo e a decepção ao chegar, retratada no refrão da música: "Brinquei com o mal, brinquei, sorri quando matei. Eu vim pra ser melhor, cheguei aqui, chorei". 
Além da música Andarilho, fazem parte dessa temática as seguintes músicas: 0 Vaqueiro e o Pescador, Rasga Nordeste e Pau-dearara. Um percentual de 5,13\% que, somado aos 17,94\% relativos aos temas históricos, apontam para um total de $23,07 \%$ na discografia do artista. Um número considerável dentro da produção de Antonio Carlos Nóbrega que não deixa de remeter a duas outras propostas do Armorial: a primeira, relativa à identificação dos temas históricos no seu trabalho, diz respeito à formação do povo brasileiro a partir do branco, negro e índio. Novamente, o Armorial se faz aí presente. A identidade nacional, compreendida por Suassuna, também se baseava na mistura dessas três raças, sendo a influência ibérica, expressão de peso para a definição nacional. A outra proposta, já evidenciada no primeiro capítulo do presente estudo, refere-se à identificação do núcleo temático Nordeste na produção do artista. Essa temática está bem presente na elaboração dos trabalhos dos armorialistas, que apontam a região nordestina como detentora de características singulares, portadora da expressão mais autêntica da cultura brasileira.

\section{As imagens como palavras: um outro texto}

O princípio de aproximar palavras e imagens está no cerne do fazer artístico do Movimento Armorial. Foi através do trabalho de ilustração d'A Pedra do Reino que Ariano Suassuna deu continuidade a sua produção em torno das artes plásticas. Essa e outras experiências anteriores em desenho, pintura e tapeçaria serviriam, mais adiante, para a produção dos álbuns de iluminogravuras, quando ele aprofundou ainda mais a integração entre texto e ilustração, representando cada álbum um livro de poemas.

O sonho de unir o texto literário e a imagem num só emblema, para que a Literatura, a Tapeçaria, a Gravura, a Cerâmica e a Escultura falem, todas, através de imagens 
concretas, firmes e brilhantes, verdadeiras insígnias das coisas. Insígnias de qualquer maneira desenhadas, gravadaseiluminadas - sobre surpefícies de pedra, de barro-queimado, de tecido, de couro, de áspero papel, ou, então, modeladas pela forma e pela imagem da palavra. (SUASSUNA apud NEWTON JÚNIOR, 1999, p. 123).

Em Antonio Carlos Nóbrega, as imagens também vão cumprir uma função determinante em relação às propostas preconizadas pelo Movimento Armorial. A partir dessa perspectiva, abrimos aqui um espaço para proceder a uma leitura cursiva das associações de imagens e palavras que estão nas capas de discos do artista. Tais aspectos vêm presentes, inclusive, no cenário de suas apresentações e na sua caracterização em palco, juntamente com seus músicos, explorando esse universo com fortes representações pictóricas.

A capa do disco Na pancada do Ganzá apresenta o artista situado ao lado direito, portando uma rabeca, numa foto posada, ocupando todo esse lado da capa. Pode-se identificar, num segundo plano, uma espécie de paisagem rural noturna, com um possível candeeiro iluminando a frente de uma casa de taipa, dando um sentido bucólico ao ambiente. A predominância de tonalidades pastéis também acentua o caráter mais rural à imagem.

O título Na Pancada do Ganzá vem situado do lado esquerdo inferior da capa, justamente no ponto de dispersão do campo de visão, depois do olhar percorrer todos os elementos, no ponto de saída. A disposição dos elementos evidencia uma preocupação no equilíbrio da capa, com as chamadas zonas mortas devidamente ocupadas, já que o braço da rabeca se estende até a parte superior direita. O candeeiro também se localiza num ponto de equilíbrio, preenchendo um espaço vazio da capa. o título do 
disco vem todo numa tonalidade escura que se confunde com a cor da capa no seu segundo plano, propiciando um aspecto tosco ainda mais intenso.

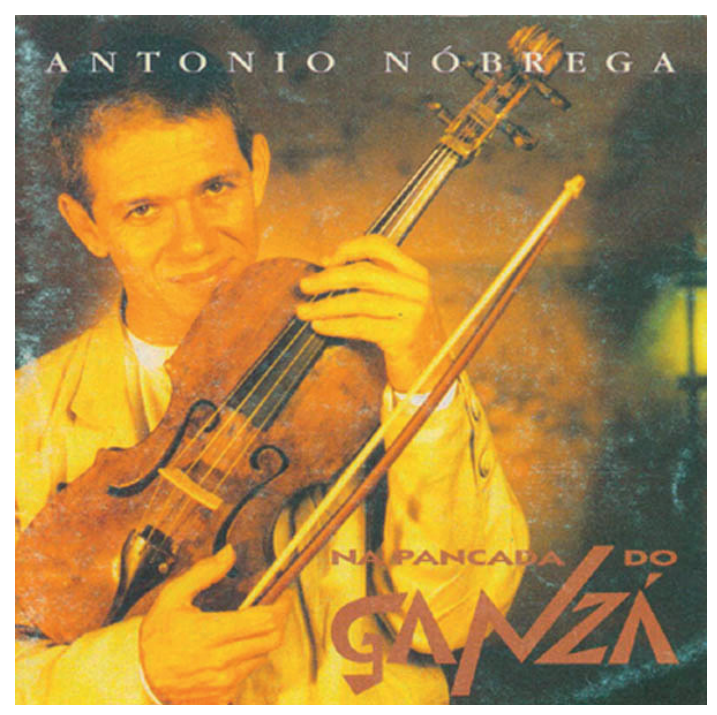

FIGURA 2 - Capa do disco Na Pancada do Ganzá

Nesse primeiro disco, Nóbrega trabalha a presença de elementos ligados ao popular. Além da presença de um instrumento de origem popular, a rabeca, a imagem remete ao meio rural, com a presença de um candeeiro e de uma casa de taipa, ligados diretamente aos aspectos do homem do Sertão, no seu espaço de vida natural, como ele é retratado. 0 próprio título do disco é também o título de uma música de autoria de Nóbrega, em parceria com Wilson Freire, e trata de elementos ligados à cultura popular. 
O disco Madeira que cupim não rói (Na Pancada do Ganzá II) tem sua ordem invertida, com o músico Antonio Carlos Nóbrega ocupando toda a extensão esquerda do disco, portando um urucungo ${ }^{8}$. Novamente numa foto posada, volta-se a ver a preocupação com as chamadas zonas mortas. Ao lado direito, o título do disco divide espaço com um pedestal, com destaque para a presença da rabeca.

Ao fundo, um cenário em tonalidade cinza faz florescer um sentimento de nostalgia, com a presença evidente do Carnaval, através da identificação de confetes caindo do alto. Um detalhe importante nessa capa é em relação à indumentária do músico, que remete a um período clássico, com um detalhe - o material dessas vestes seria feito de forma artesanal. Observa-se que existe uma preocupação em fundir elementos populares e eruditos também nesse trabalho. A rabeca não é colocada à toa na parte inferior direita da capa. Ela está ali, representando o elemento popular que divide espaço com outros aspectos, mais eruditos, como o próprio traje do artista.

8 O urucungo, como afirma o próprio Antônio Carlos Nóbrega, representa o "elo perdido" entre o berimbau e a rabeca, assim como a rabeca fica entre o violino moderno e o urucungo, observando-se assim uma perquirição etnomusicológica. 


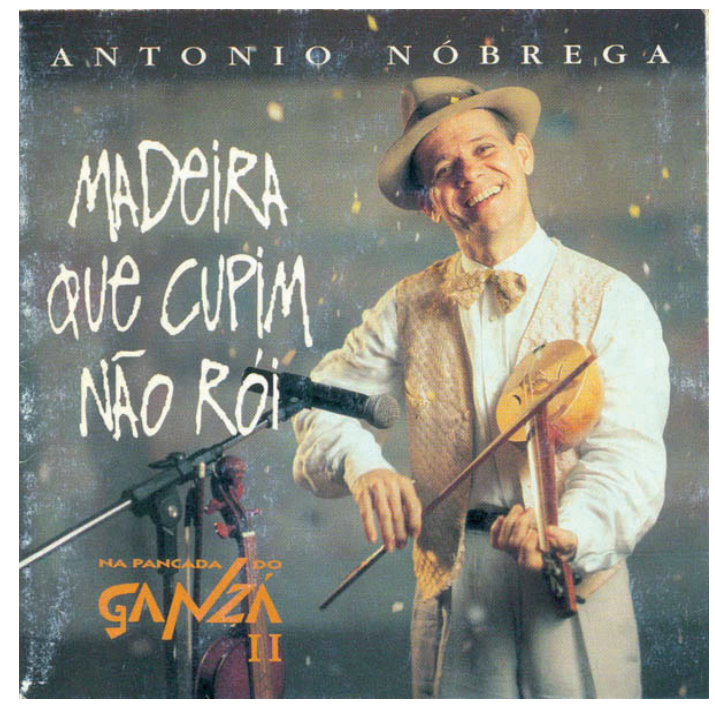

FIGURA 3 - Capa do disco Madeira que cupim não rói

Na capa, o título Madeira que cupim não rói, nome de uma consagrada marcha de bloco do Carnaval de Pernambuco, de autoria do músico Lourenço da Fonseca Barbosa, o Capiba, apresenta-se como riscos numa casca de árvore. Ou seja, a madeira foi riscada, mas o cupim não estragou a madeira. Na verdade, a letra da música trata da história de um dos blocos de carnaval mais tradicionais de Recife, que tem em sua temática a injustiça na avaliação de uma comissão julgadora. Mesmo injustiçado, o bloco não desiste e se apresenta como o verdadeiro campeão do Carnaval.

Pernambuco falando para o mundo, como podemos verificar, apresenta o artista numa foto tirada de um ângulo superior, com Nóbrega ocupando o lado esquerdo da capa, tendo em suas mãos mais uma vez a rabeca. o título do trabalho apresentase do lado direito, no intuito de proporcionar um equilíbrio da capa. 
Aspecto novo neste disco, em relação aos trabalhos anteriores, diz respeito à fotografia do artista, numa espécie de moldura, através de um desenho do artista plástico Dantas Suassuna. A foto apresenta também um exemplo de foto em perspectiva, com as pinturas dando uma impressão de movimento à foto.

Ao contrário dos outros dois trabalhos anteriores, quando Antonio Carlos Nóbrega se apresentava numa foto posada, neste trabalho, o artista aparece em movimento, portando a rabeca, como se estivesse executando um dos seus movimentos característicos. Seus trajes apresentam as mesmas pinturas e desenhos de Dantas Suassuna que, diga-se de passagem, é um dos representantes do Movimento Armorial na área das artes plásticas.

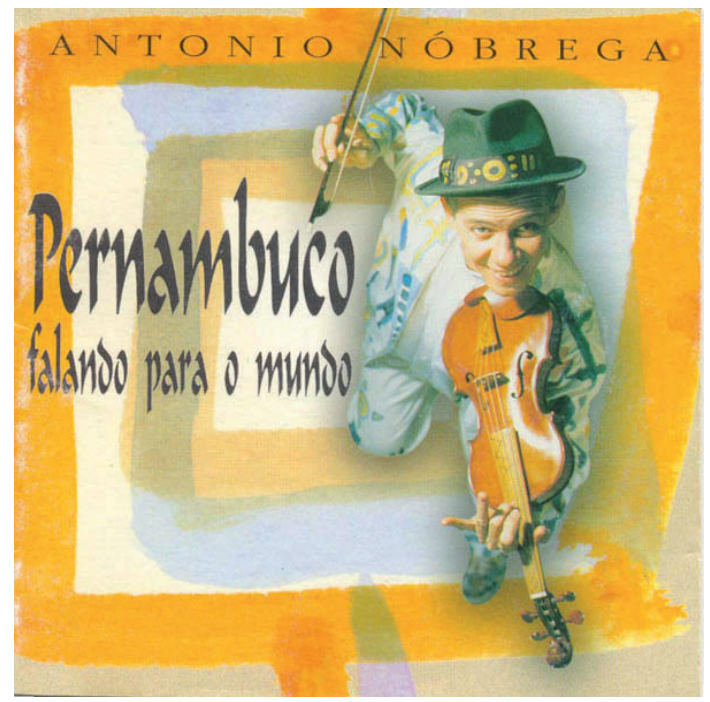

FIGURA 4 - Capa do disco Pernambuco falando para o mundo 
Trata-se de um disco que apresenta novamente o Carnaval, com marchas consagradas e outras músicas de Nóbrega, executadas ao ritmo pernambucano. As cores vivas utilizadas remetem a esse ambiente de festa que magnetiza o público, com destaque para a utilização do amarelo, eficaz no processo de comunicação e que proporciona, ainda, uma associação afetiva, correspondente à alegria e à energia.

Mais uma vez, são encontradas características que evidenciam elementos populares na obra de Nóbrega: a presença da rabeca, a sua indumentária, além do próprio título do trabalho e título de uma das músicas do disco, de autoria de Nóbrega e Wilson Freire, que diz respeito a elementos pertencentes ao imaginário coletivo nordestino.

Em O Marco do Meio Dia, Nóbrega aparece portando novamente a rabeca, numa foto durante apresentação em palco. Dessa vez, situado no centro da capa, os elementos que dão o equilíbrio necessário estão num segundo plano, com uma representação de Nóbrega à direita e a estrela d'Marco do Meio Dia, à esquerda.

Ao fundo, na parte inferior, o cenário lembra uma espécie de vila do Nordeste brasileiro, com casas semelhantes, umas com os muros encostados nas outras. $\mathrm{O}$ ambiente aponta para uma paisagem rural. As pinturas e desenhos presentes na indumentária e no cenário do espetáculo trazem, por sua vez, aspectos relacionados ao período medieval, na Península Ibérica, com a presença de "figuras monstruosas, bestas-feras, animais alados e todo um repertório de imagens fantásticas de inspiração árabe" (NEWTON JÚNIOR, 1999, p.124). 


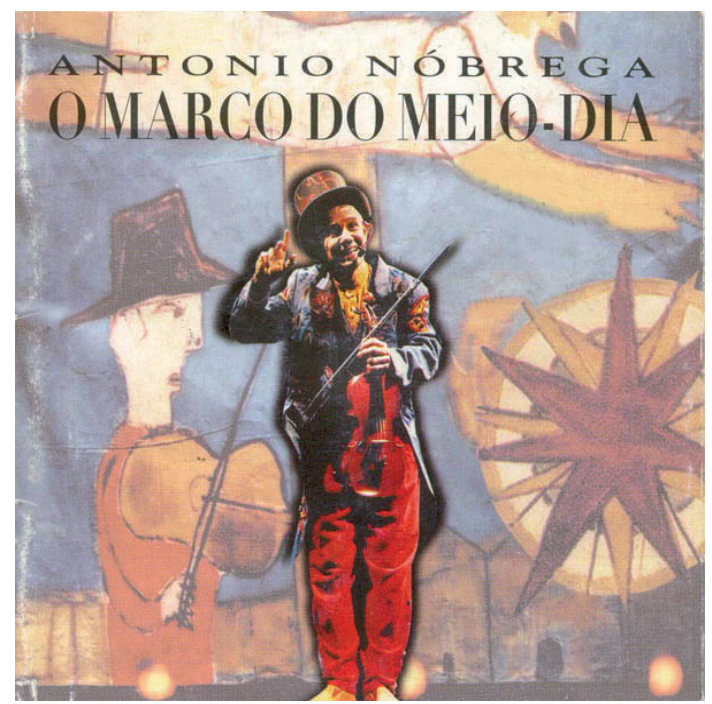

FIGURA 5 - Capa do disco O Marco do Meio Dia

Um aspecto que não vem evidente na capa, porém pode ser identificável no contexto do encarte como um todo, é a presença das iluminogravuras, que também faz parte dos trajes dos músicos e do próprio Nóbrega, que explora esses elementos, unindo-os uns aos outros e formando um todo no seu trabalho, que reflete a arte Armorial.

Já o disco Lunário Perpétuo apresenta-se com uma diversidade de elementos não comparada a nenhum dos trabalhos anteriores. A começar pelo aspecto envelhecido do material que compõe o encarte, numa alusão ao antigo livro que circulou, até meados do século XIX, no Nordeste brasileiro.

O Lunário Perpétuo era um dos livros mais lidos nos sertões do Nordeste, sendo uma das principais fontes de referência e conhecimento para as pessoas, além de bastante explorado, também, por poetas populares. Ele trazia um pouco de tudo, 
de astrologia, horóscopo, receitas médicas e mitologia, até conhecimentos agrícolas e conselhos de veterinária. Um livro, portanto, que tratava diretamente de temas ligados às necessidades das camadas mais populares. Sendo assim, a proposta de capa, necessariamente, teria que estar ligada a essa natureza e daí o aspecto envelhecido, já que se trata de um livro de circulação no século passado, desgastado pelo tempo.

Uma moldura incorpora todos os elementos da capa do disco, o que torna a leitura do objeto mais direcionada e constante, sem a dispersão do olhar, tendo em vista que o observador fixa e prende mais seu olhar em decorrência da moldura. Pode ser verificada uma preocupação com a disposição dos elementos, de forma que todos os espaços encontram-se devidamente preenchidos, sem que, no entanto, exista uma poluição visual, apesar da grande quantidade de textos contidos na capa.

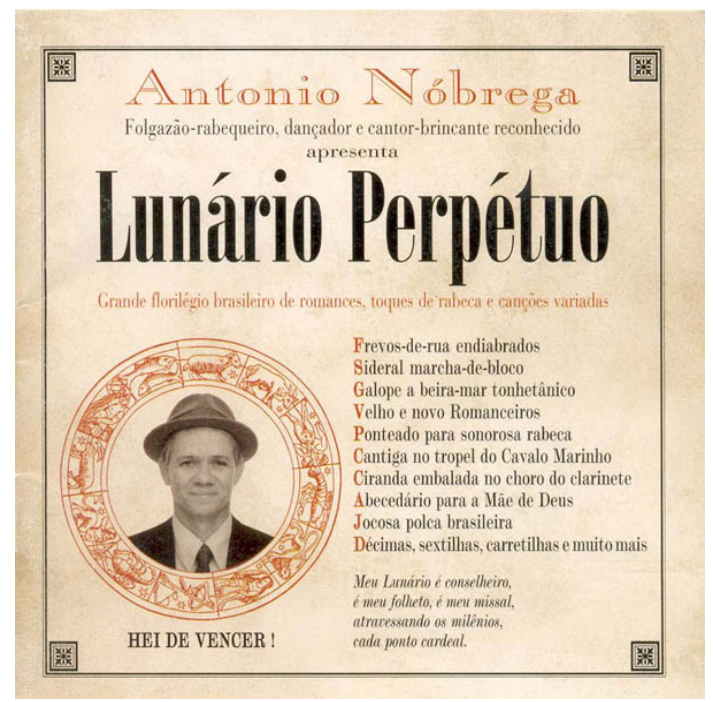

FIGURA 6 - Capa do disco Lunário Perpétuo 
Nesse trabalho, Nóbrega encontra-se localizado na parte inferior do lado direito, numa foto em preto e branco, de busto, que mais se parece com as fotos tiradas nas antigas máquinas de "lambe-lambe". Ao seu redor, uma espécie de círculo com o horóscopo e a presença de todos os signos. Esse elemento é apenas um em todo o encarte que contém uma ilustração do livro Lunário Perpétuo.

Ao lado esquerdo do disco, uma breve apresentação dos ritmos que fazem parte do conteúdo da obra, como os frevosde-rua, marchas-de-bloco, galopes à beira mar, loas, cirandas, polcas, entre outros. No ponto de saída do olhar, que se dá de cima para baixo, na diagonal, encontra-se a frase "Meu Lunário é conselheiro, é meu folheto, é meu missal, atravessando os milênios, cada ponto cardeal", que aponta para o livro como uma espécie de ponto de referência para os nordestinos.

Um aspecto chama atenção nessa obra em relação às anteriores. A ausência da rabeca com o músico. No entanto, ela aparece em dois momentos, não como representação simbólica, mas como palavra escrita. A primeira delas logo abaixo do nome do artista, num texto centralizado, que diz "Folgazãorabequeiro, dançador e cantor-brincante reconhecido". O outro momento em que a rabeca se faz presente é abaixo do título do disco, quando se verifica a frase "Grande florilégio brasileiro de romances, toques de rabeca e canções variadas".

As cores que compõem a capa do disco também foram pensadas no protótipo original, ou seja, no antigo livro. Além do preto e branco, com um fundo num certo tom pastel, que dá o envelhecimento característico da obra, a presença do vermelho dá um toque especial e de destaque para determinados aspectos do disco. A cor vermelha atua tanto no sentido de destacar pontos da obra, como também no que se refere propriamente à programação visual, associando-se à energia, esplendor, 
intensidade e glória. Não por acaso, abaixo do retrato três por quatro do artista, destaca-se a frase "Hei de vencer!".

Mais uma vez, o armorial apresenta-se de forma clara. Desde o trabalho de resgate e recriação de uma obra como o Lunário Perpétuo, pertencente às tradições e crenças do homem nordestino, o disco como um todo remete à obra original. 0 elemento erudito vem presente na breve apresentação da obra constante da capa, remetendo aos romances de origem ibérica. Os traços populares, por sua vez, estão em cada ponto do disco, inclusive no próprio sentido das frases de efeito utilizadas. Lunário Perpétuo corresponde, também, a uma música que integra o trabalho.

Composta por Nóbrega, Wilson Freire e Braulio Tavares, a sua letra fala da representatividade e utilidade do livro para os nordestinos.

\author{
Meu lunário tem antigas \\ alquimias de almanaque. \\ Já enfrentou intempéries, \\ roubos, incêndios e saques: \\ dos homens, das traças, das garras das eras. \\ Carrega segredos, decifra quimeras, \\ venceu todos os ataques. \\ $[\ldots]$ \\ O meu Lunário Perpétuo \\ é meu livro precioso, \\ minha Cartilha primeira, \\ minha Bíblia de Trancoso. \\ João Grilo, Chicó, Malazartes, Mateus, \\ os órfãos da terra, os filhos de Deus, \\ heróis do Maravilhoso.
}




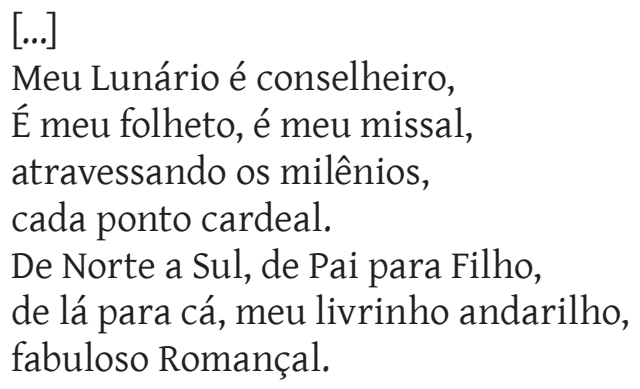

Outro ponto que merece destaque na análise refere-se a um elemento presente no Lunário Perpétuo, identificado como o trabalho do músico que carrega em si o maior número de características e possibilidades a serem verificadas dentro do Armorial. Esse elemento diz respeito à frase "Hei de Vencer!". Verifica-se aí uma preocupação dentro do Armorial que diz respeito à abordagem dos temas relativos à busca de uma melhor condição de vida para o povo, sem perder de vista a valorização, o resgate e a preservação de valores culturais próprios ao país.

Ao trazer os diversos elementos presentes no disco Lunário Perpétuo, Nóbrega mais uma vez trabalha com a perspectiva Armorial de recriação das artes, presente sob os diversos aspectos. Desde a caracterização da capa do disco, com os vários elementos presentes no que se refere às temáticas extraídas diretamente do livro Lunário Perpétuo, até os temas das músicas do trabalho.

Os discos Na Pancada do Ganzá, Madeira que cupim não rói, Pernambuco falando para o mundo, O Marco do Meio-Dia e Lunário Perpétuo apresentam aspectos vários que caracterizam o Movimento Armorial. Tais aspectos poderiam ser reconhecidos no resgate de elementos pertencentes às tradições e crenças do homem nordestino. Isso sem perder de vista os aspectos 
eruditos, seja na presença de instrumentos de origem ibérica, como é o caso do urucungo, presente na capa do disco Madeira que cupim não rói; seja, ainda, nas indumentárias do artista, como acontece n'O Marco do Meio-Dia, com a presença das iluminogravuras, criadas por Ariano Suassuna, que como foi visto, em momento anterior, tem origem na iluminura medieval.

No que se refere aos elementos que caracterizam o popular nas capas dos discos de Nóbrega, esses vêm representados de forma ainda mais acentuada. Um aspecto importante que ganha destaque nesse contexto é a presença constante da rabeca em todos os trabalhos do artista. Nos cinco discos, o instrumento aparece sempre presente, seja por inteiro, como nos discos $\mathrm{Na}$ Pancada do Ganzá, Pernambuco Falando para o Mundo e 0 Marco do Meio-Dia; seja em parte, como no Madeira que cupim não rói, quando a rabeca vem presa ao pedestal de um microfone; seja, finalmente, através da representação escrita, a palavra, como acontece no Lunário Perpétuo.

Seguindo as referências propostas pelo Movimento Armorial, Nóbrega mantém uma base de origem ibérica e da arte popular nordestina. O que se registra, enfim, é a presença constante e rica de elementos eruditos e populares nos discos de Antonio Carlos Nóbrega. Dessa forma, as capas da discografia do artista representam, também, um espaço que caracteriza a permanência da arte armorial no atual cenário cultural brasileiro e atuam ainda como elementos identificadores perante os diversos públicos, que se encontram e reencontram na diversidade de formatos que expressam o fazer artístico do Armorial sob diversos prismas. 